\title{
Pattern of Kirtland's warbler occurrence in relation to the landscape structure of its summer habitat in northern Lower Michigan
}

\author{
Xiaoming Zou ${ }^{1}$, Corinna Theiss and Burton V. Barnes \\ School of Natural Resources, The University of Michigan, Ann Arbor, MI 48109-1115, USA
}

Keywords: Landscape ecology, landscape ecosystems, landscape structure, Kirtland's warbler, endangered species, jack pine-oak forest

\begin{abstract}
Studies of the endangered Kirtland's warbler in relation to landscape ecosystems were conducted from 1986-1988 on a large wildfire-burn surrounding Mack Lake in southeastern Oscoda County, Michigan. A landscape ecosystem approach was used to distinguish low- and high-elevation segments of the landscape, as well as 11 local ecosystem types. The ecosystems were distinguished by physiography, microclimate, soil, and vegetation. The early occurrence of the warblers was strongly related to landscape structure, i.e., to the broad low- and high-elevation areas and the local ecosystem types within them. Territories of male warblers were observed in 5 of the 11 ecosystems. The five ecosystem types where warblers were observed were characterized by (1) a physiography of level or rolling terrain; (2) soil series of Grayling, Graycalm, Montcalm, or Rubicon; (3) uplands with relatively warm temperature during the breeding season; (4) vegetation dominated by low sweet blueberry, bearberry, wintergreen, northern pin oak, blue stem grasses, and hair cap moss; and (5) canopy of relatively tall, dense, and patchy jack pine and oak. Landscape structure appears to be an important factor affecting the occurrence of the warbler in its summer habitat in northern Lower Michigan.
\end{abstract}

\section{Introduction and background}

The Kirtland's warbler (Dendroica kirtlandii) is one of the rarest endangered songbirds in North America. Restricted to northern Lower Michigan, its summer habitat comprises an area about $120 \times$ $160 \mathrm{~km}$. All known nests have been located within 13 counties for the past several decades (Probst 1985 ; 1986). Warbler habitat is characterized by relatively dense, patchy jack pine (Pinus banksiana Lamb.) or jack pine and northern pin oak (Quercus ellipsoidalis E.J. Hill) stands that range from 6 to 23 years old and are 1.7 to $5.0 \mathrm{~m}$ tall (Probst 1987).
The warblers rarely nest outside of jack pine forest.

The first census of the warbler population was conducted in 1951, and a total count of 432 singing males was reported (Mayfield 1953). In the next census in 1961, 502 males were reported (Mayfield 1962). The third census in 1971 revealed a marked drop to 201 males (Mayfield 1972). The principal reasons for this decline appeared to be nest parasitism by the brown-headed cowbird (Molothrus ater) and limited suitable habitat (Ryel 1981). The population has been censused each year since 1971 , and a strong effort has been made to control the cowbird by yearly trapping (Kelly and DeCapita 


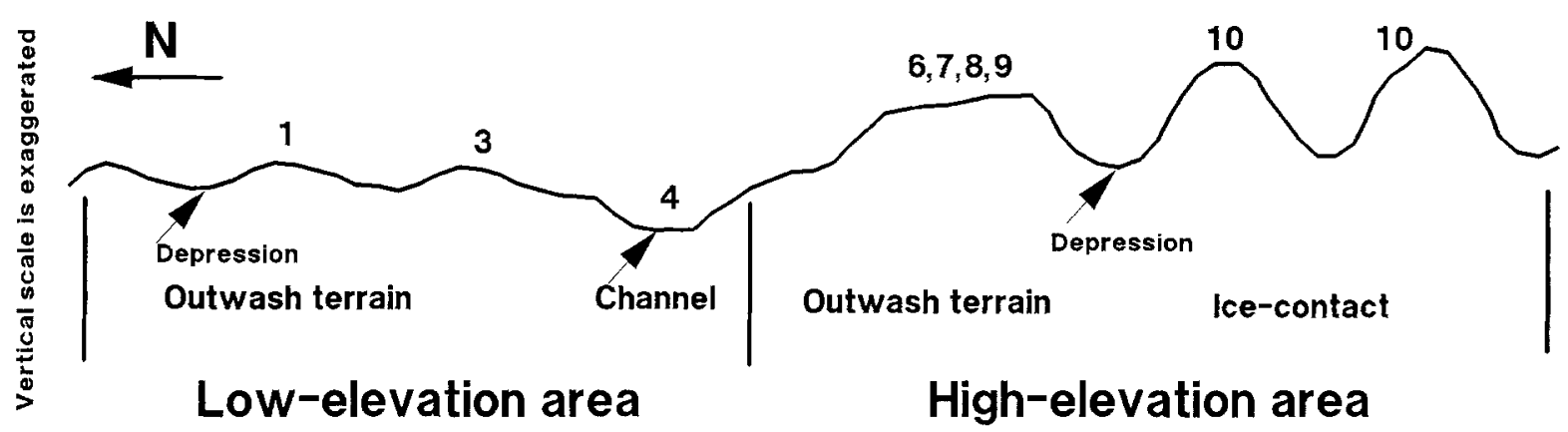

Fig. 1. A diagram illustrating the low-elevation and high-elevation areas of the Mack Lake burn study area. Numbers indicate the different landscape ecosystem types and their locations.

1982). In addition, large-scale planting of jack pine has been conducted each year since 1980 , and the known habitats of the warbler have been protected from human disturbance (Byelich 1976). However, no increase in the warbler population has occurred over the ensuing years. The population had remained more or less stable (average male population was $205 \pm 20$ ) between 1971 and 1988 .

Much of the previous research on the warbler has been focused on its life history, biological characteristics, and territorial behavior (Mayfield 1960; Ryel 1978; Trautman 1979; Buech 1980; Walkinshaw 1983; Probst 1986). Little attention has been paid to its habitat at a landscape scale. Therefore, research was initiated in 1986 to better understand Kirtland's warbler habitat by identifying and describing the landscape ecosystem types of the Mack Lake burn. This burn of about 9,550 ha occurred in 1980, and by 1986 jack pine trees had grown to a suitable height for colonization by the warbler. Jack pine height and patchiness and the character of the ground-cover vegetation are critical in the first stage of warbler occupancy of a stand (two to four years). Because warblers may occupy an area for 15-20 years, and stands change rapidly during this period, the habitat characters important for warbler occupancy may also change during this time.

Warblers entered the Mack Lake burn in June of 1986 , and $71 \%$ of the 14 singing males censused in 1986 were found in the topographically higher terrain of the southern part of the site that was characterized by relatively dense and tall jack pines (Barnes and Bosio 1986). In 1987, 61\% of the 28 warblers were found in the higher terrain (Barnes et al. 1989). Because the elevation of the terrain affected warbler density, the burn was arbitrarily subdivided into (1) a low-elevation area of flat to rolling outwash and post-glacial outwash channels in the northern part of the site, and (2) a high-elevation area made up of glacial outwash and hilly ice-contact terrain to the south (Fig. 1). Besides being slightly higher in elevation, the high-elevation area has a warmer microclimate, finer soil texture, and more diverse plant species (Zou 1988; Barnes et al. 1989). Eleven local ecosystem types were also identified - five in the low-elevation area and six in the high-elevation area (Barnes et al. 1989). In 1988 a field study was designed to determine the specific location of singing males in relation to these ecosystem types.

The purposes of this paper are:

(1) to provide an overview of the occurrence of warblers in the Mack Lake burn area during the initial three years (1986-88) of their occupancy of the area,

(2) to present the results of field studies in 1988 to relate warbler occurrence and density to specific ecosystem types, and

(3) to describe the biological and physical attributes of these ecosystems.

\section{Methods}

\subsection{Study Area}

The study site was located in an area surrounding Mack Lake $\left(44^{\circ} 38^{\prime} \mathrm{N}, 84^{\circ} 08^{\prime} \mathrm{E}\right)$ in southeastern 
Oscoda County of northern Lower Michigan. The forest covering the study area was probably originally dominated by various combinations of jack pine, red pine (Pinus resinosa Ait.), and northern pin oak. On May 10, 1980, a prescribed burn initiated a wildfire that burned approximately 9,550 ha of forest land around Mack Lake (Simard et al. 1983). Jack pine regenerated over much of the burned area.

Oscoda County has a modified continental climate (Michigan Weather Service 1974), with minimal influence from Lake Michigan because of a higher sheltering plateau to the west. A weather station near the study area at Mio has a higher average maximum temperature, a lower average minimum temperature, and a lower annual precipitation than surrounding weather stations (Michigan Weather Service 1974). The entire area is a mosaic of different ecosystems each of which can be distinguished by using physiographic, soil, and vegetative features (Barnes et al. 1989).

\subsection{General approach}

Landscape ecosystem types were identified and described by a multi-factor ecological approach that had previously been developed and applied in Upper Michigan (Barnes et al. 1982; Pregitzer and Barnes 1984; Spies and Barnes 1985) and in southern Michigan (Archambault et al. 1990). The approach was derived from a method used in the southwestern German state of Baden-Württemberg for over 40 years in multiple-use forest management (Barnes 1984). The Michigan approach uses reconnaissance followed by plot sampling and data analysis to identify ecosystem types that are distinguished by their physiography, microclimate, soil, and vegetation. This method yielded eleven types (Barnes et al. 1989). The types were defined in a typological sense and were not mapped.

The number and geographic location of warblers on the burn was determined in June each year by a census of singing males. This official census is directed by personnel of the Huron-Manistee National Forests, U.S.D.A. Forest Service, and the Michigan Department of Natural Resources, to- gether with members of the Kirtland's Warbler Recovery Team.

\subsection{6-87 field methods}

Sixty-four plots $(10 \times 20 \mathrm{~m})$, sampled in 1986 and 1987 (Barnes et al. 1982; Spies and Barnes 1985), were used to help determine and describe the ecosystem types (Barnes and Bosio 1986; Barnes et al. 1989). Physiographic variables included elevation, landform, slope aspect, and position. A $150-\mathrm{cm}$ deep soil pit, randomly assigned to the east or west side of a plot, was dug and all horizons were described; data were taken on horizon depth, field $\mathrm{pH}$, texture, structure, color, percent gravel and cobbles, rooting depth, earthworm activity, and drainage class. A soil sample was collected for each layer of the B and C horizons. Soil texture was described in the field (Thien 1979) and determined in the laboratory, using the hydrometer method of Gee and Baunder (1986). Soil pH was determined in the laboratory using a $1: 1$ soil : water suspension using the glass electrode method of McLean (1982). Vegetative variables measured in field plots included percent coverage of each species, density and size of tree species, annual growth of jack pines, and number of plant species on each plot (Barnes et al. 1989).

In 1987, the locations of 28 singing male warblers were determined and recorded on a map of the area. Each warbler location was then field checked and its ecosystem type determined.

\subsection{8 field methods}

In 1988, 78 singing male warblers were found on the Mack Lake burn and their locations plotted on a map of the burn by the census team organized by the Kirtland's Warbler Recovery Team. With the assistance of the U.S. Fish and Wildlife Service team of Cameron Kepler, Paul Sykes, and Carol Bocetti, the territories of 38 warblers were located by sightings of singing male warblers. Each of these territories was defined by ecosystem type. Eighteen sample plots were located directly in the territory of 
a warbler to verify the ecosystem type. Plot sampling was conducted as in 1986-87. In the office, a distance from the midpoint of a territory to the midpoint of that of its closest neighbor was measured using the 1988 Official Warbler Census Maps (Michigan Department of Natural Resources, Lansing, MI). Distances between warbler territories for each ecosystem type were determined and placed in one of seven distance classes (100-250, $251-400,401-550,551-700,701-850,851-$ $1000,1001-1150 \mathrm{~m})$. The number of warblers for each distance class was determined for each ecosystem type.

\subsection{Data analyses}

Four ecosystem types $(1,6,8,10)$ where warblers had been observed in 1987 and three types $(3,4,9)$ where they had not been observed were selected for analysis (Zou 1988). Using the 1986-87 data from 64 plots, stepwise discriminant analysis (Jenrich 1977) was used to select variables that differed significantly among these seven ecosystem types. Variables with significance values smaller than 0.15 were included and subjected to principal component analysis (Mardia et al. 1979). The first 20 principal components were used to analyze differences among the seven ecosystems by canonical variate analysis (Williams 1981). Differences among ecosystem types were examined using analysis of variance (ANOVA). Duncan's multiple range test (Neter and Wasserman 1985; Steel and Torri 1980) was used to determine significances among ecosystems. The significance level for both tests was set at 0.05 .

\section{Results and discussion}

\subsection{Pattern of warbler occurrence}

During the first three years of occupancy, more warblers occupied the high-elevation area than the low-elevation area (Table 1); the relative positions of the two areas are shown in Fig. 1. In 1987 and 1988 all male warblers were observed to occur in 5
Table 1. Number of male Kirtland's warblers in the lowelevation area vs. the high-elevation area for 1986-1988 on the Mack Lake burn, Oscoda County, northern lower Michigan.

\begin{tabular}{lcll}
\hline Year & 1986 & 1987 & 1988 \\
\hline Low-elevation outwash & 4 & 12 & 31 \\
High-elevation outwash & 10 & 16 & 47 \\
\hline
\end{tabular}

Table 2. Distribution of male Kirtland's warblers in 1987 and 1988 by local landscape ecosystems on the Mack Lake burn, Oscoda County, northern lower Michigan.

\begin{tabular}{lcc}
\hline Ecosystem type & \multicolumn{2}{c}{ Number of warblers } \\
\cline { 2 - 3 } & $1987^{1}$ & $1988^{2}$ \\
\hline 1 & 12 & 22 \\
6 & 3 & 2 \\
7 & 3 & 5 \\
8 & 8 & 7 \\
10 & 2 & 2 \\
Total & - & - \\
\hline
\end{tabular}

${ }^{1}$ All warblers occupying burn.

${ }^{2} \mathrm{~A}$ subsample of warblers whose territories were identified and studied in detail.

of the 11 ecosystem types. Patterns of warbler occurrence for 1987 and 1988 are shown in Table 2. In both years, more warblers occurred in Ecosystem type 1 than any other single ecosystem due to its widespread occurrence. Because neither the ecosystem types nor the exact territory boundaries have been mapped, the pattern of occurrence of the warblers for nesting and feeding cannot be determined. The ecosystems occur in a mosaic in the landscape, and it is likely that a warbler pair utilizes more than one of the ecosystem types for its activities. However, Ecosystems 1, 6, 7, 8, and 10 appear to be critical for warblers at this stage.

The average distance from a singing male territory to its closest neighbor was least in Ecosystem types 7 and 8 (365 and $269 \mathrm{~m}$, respectively) (Table 3 ), and it was greatest for Ecosystem type 10 (522 $\mathrm{m})$. Therefore, the density of the singing male warblers was the highest in Ecosystem type 7 and 8, and the lowest in Ecosystem type 10. Ecosystem type 1 was intermediate. Ecosystem type 6 was not included in this analysis because the two warblers were 
Table 3. Means and standard deviations of distances between Kirtiand's warbler territories in 1988 to their nearest neighbor by ecosystem types.

\begin{tabular}{lllll}
\hline Ecosystem types & 1 & 7 & 8 & 10 \\
\hline $\begin{array}{l}\text { Mean(m) } \\
\begin{array}{l}\text { Standard } \\
\text { deviation(m) }\end{array}\end{array}$ & 435 & 365 & 269 & 522 \\
\hline
\end{tabular}

their own closest neighbors and no variance among distance was available for the analysis.

The distribution of singing male warblers in distance classes varied significantly $(\mathrm{P}<0.05)$ among ecosystem types. Forty-two percent and $72 \%$ of the singing male warblers had territories within a distance of $100-250 \mathrm{~m}$ from one another in Ecosystem types 7 and 8, respectively (Fig. 2). None of the warbler territories was located at a distance greater than $700 \mathrm{~m}$ from one another in these ecosystems. In contrast, only $36 \%$ of the singing male warblers were located within a distance of 100-250 $\mathrm{m}$ from one another in Ecosystem type 1 , and $24 \%$ of the warbler territories were located at distances greater than $700 \mathrm{~m}$ from one another. Of course, Ecosystem type 10 warblers were more distant from one another.

\subsection{Multifactor comparison of ecosystem types}

Marked differences were found among 7 ecosystem types using the first 20 principal components (Figs. 3 and 4). The cumulative variation for the first 20 principal components was $91 \%$ and that for the first 3 canonical variates was $90 \%$. A total of $82 \%$ of the information in 56 variables, selected by stepwise discriminant analysis, was contained in the first 3 canonical variates.

The presence of the warbler in an ecosystem type is associated with medium values of canonical variate 2 (Fig. 3; Ecosystems 1, 6, 8, and 10). Ecosystems with high or low values were not observed to have warblers (Fig. 3; Ecosystems 3, 4, and 9). Ecosystems having high values for canonical variate 3 , as well as low values for canonical variate 1 (Fig. 4; Ecosystems 3, 4, and 9), were not favor- able habitat in 1987. However, ecosystems with either high values of canonical variate 1 or low values of canonical variate 3 (Fig. 4; Ecosystems 1, 6,8 and 10 ) were favored by warblers.

High values of canonical variate 1 were mainly associated with high-elevation terrain, non-banded soil, soil lacking layers of gravel and cobbles, low soil $\mathrm{pH}$, the presence of black huckleberry (Gaylussacia baccata (Wang.) K. Koch), high coverage of northern pin oak, and low coverage of serviceberry (Amelanchier sanguinea (Pursh) DC.), sand cherry (Prunus pumila L.), and wild rose (Rosa blanda Ait.) (Table 4).

High values of canonical variate 2 (Fig. 3) were mainly associated with depressions or outwash channels, the presence of gravel and cobble layers, absence of black huckleberry, and high coverage of serviceberry. Low values of canonical variate 2 were primarily determined by presence of banded soils and by low coverage of northern pin oak, whereas medium values were associated with uplands and relatively pure sand soils.

High values of canonical variate 3 were primarily associated with hilly topography and outwash channels, the presence of banded soil or gravel and cobble layers, and the presence of rice grass (Oryzopsis asperifolia Michx.) and false Solomonseal (Smilacina racemosa (L.) Desf).

\subsection{Description of ecosystem types}

Twenty-three physiographic, soil, and species variables significantly distinguished the ecosystem types (Table 4). Of these, 10 were physiographicsoil variables, 6 were related to jack pine and oak, and 10 were descriptors of ground-cover vegetation. The ecosystems are described below from data presented in Table 4 . The first set of ecosystems (1, $6,8,10)$ are those favorable to warbler occupancy and have the following general conditions: (1) flat to rolling topography on outwash or ice-contact terrain; (2) Grayling, Graycalm, Montcalm, or Rubicon soil series; (3) relatively warm temperatures during time of warbler occupancy; (4) vegetation dominated by low sweet blueberry (Vaccinium angustifolium Ait.), bearberry (Arctostaphylos uva- 


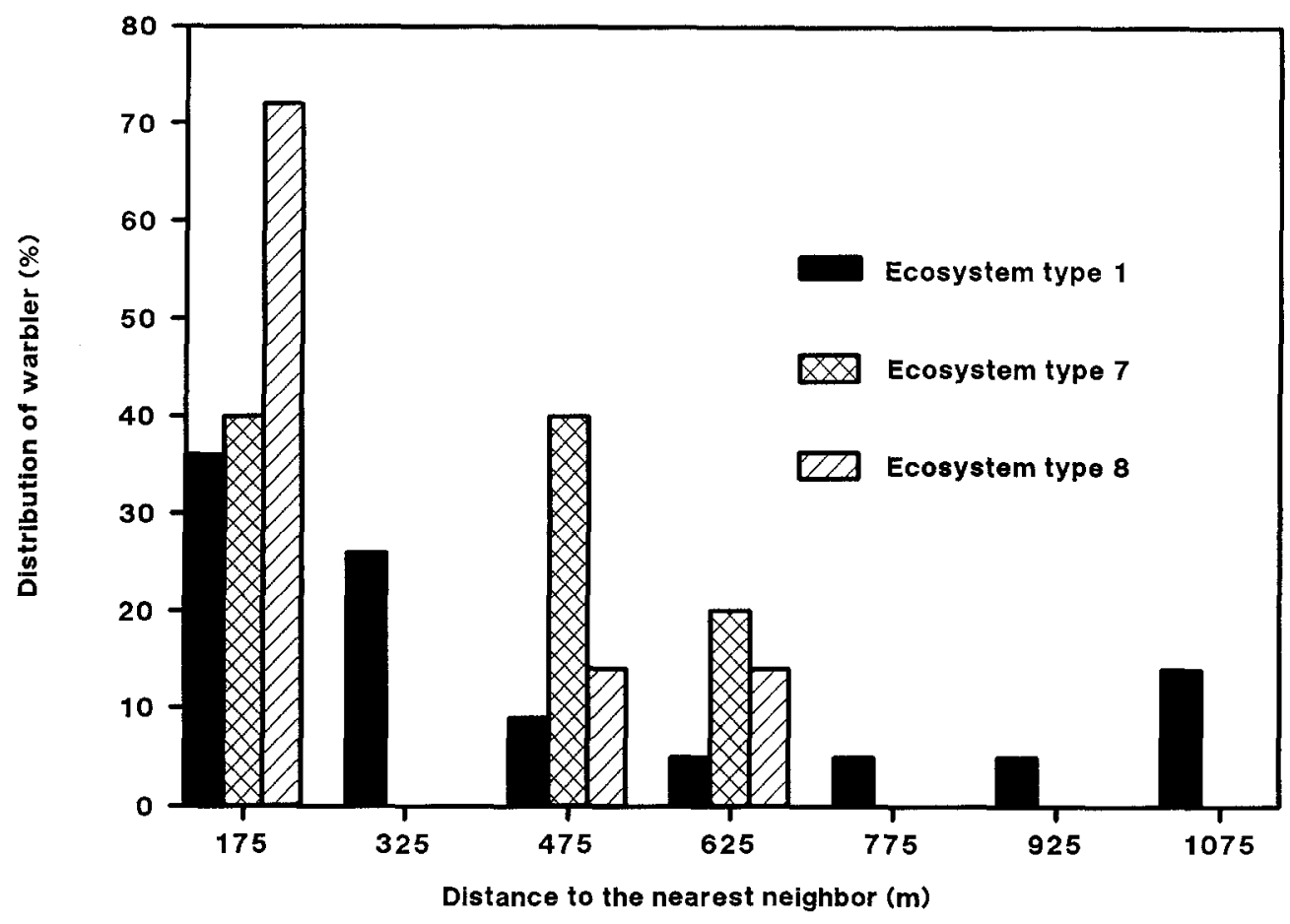

Fig. 2. Distribution of warblers (\%) by the distance (m) to their nearest neighbor. The percentage of warblers in each Ecosystem type, 1, 7, 8 (y-axis), was plotted over the mean distance to the nearest neighbor's territory. For example, $40 \%$ of warblers in Ecosystem 7 were in the $100-250 \mathrm{~m}$ class (mean $=175 \mathrm{~m}$ ), $40 \%$ were in the $401-550 \mathrm{~m}$ class (mean $=475 \mathrm{~m}$ ), and $20 \%$ were in the $551-700 \mathrm{~m}$ class $($ mean $=625 \mathrm{~m})$.

ursi (L.) Spreng.), wintergreen (Gaultheria procumbens L.), northern pine oak, blue stem grasses ( $A n$ dropogon gerardii Vitman, A. scoparius Michx.), or hair cap mosses (Polytrichum piliferum Hedw., $P$. juniperinum Hedw.); and (5) relatively tall, dense jack pine.

Ecosystem 1, located on level and rolling terrain (not in depressions, Fig. 1) of the low-elevation area, has well-sorted sand soil in the top $400 \mathrm{~cm}$ that lacks banding, relatively low $\mathrm{pH}(5.0)$ of the $30-$ $150 \mathrm{~cm}$ soil layer, and soil series of Grayling and Rubicon. Jack pine is generally short, $66 \mathrm{~cm}$ in 1985. Very few northern pin oaks are present, and the dominant ground-cover species are low sweet blueberry, blue stem grasses, sand cherry, bearberry, and hair cap mosses.

Ecosystem 6 also has a high proportion of wellsorted sand but is located on the high-elevation area. The soil series are typically Grayling and Graycalm. Vegetation is more diverse in plant species than in Ecosystem 1; for example, 11 shrub spe- cies were recorded in this ecosystem as compared to 5 for Ecosystem 1. The coverage of sand cherry is higher than in most other ecosystems. Northern pin oak often is one of the dominant species.

Ecosystem 8 is characterized by textural bands of sandy loam to silt loam of $5-10 \mathrm{~cm}$ in the upper 150 $\mathrm{cm}$ of soil. The soil series is commonly Montcalm. Northern pin oak is relatively abundant and its average height $(1.9 \mathrm{~m})$ is greatest of all ecosystems. Ground cover is dominated by low sweet blueberry, northern pin oak, bracken fern (Pteridium aquilinum (L.) Kuhn), sweet fern (Comptonia peregrina (L.) Coulter), and wintergreen.

Ecosystem 10 is found on the upper slopes of depressions and tops of hills in the ice-contact terrain. The soil series is mostly Rubicon and Grayling. Oak coverage is greatest in this ecosystem. Ground vegetation is dominated by low sweet blueberry and black huckleberry. Other plant species include Populus grandidentata Michx., Hamamelis virginiana L., and Acer rubrum L. 


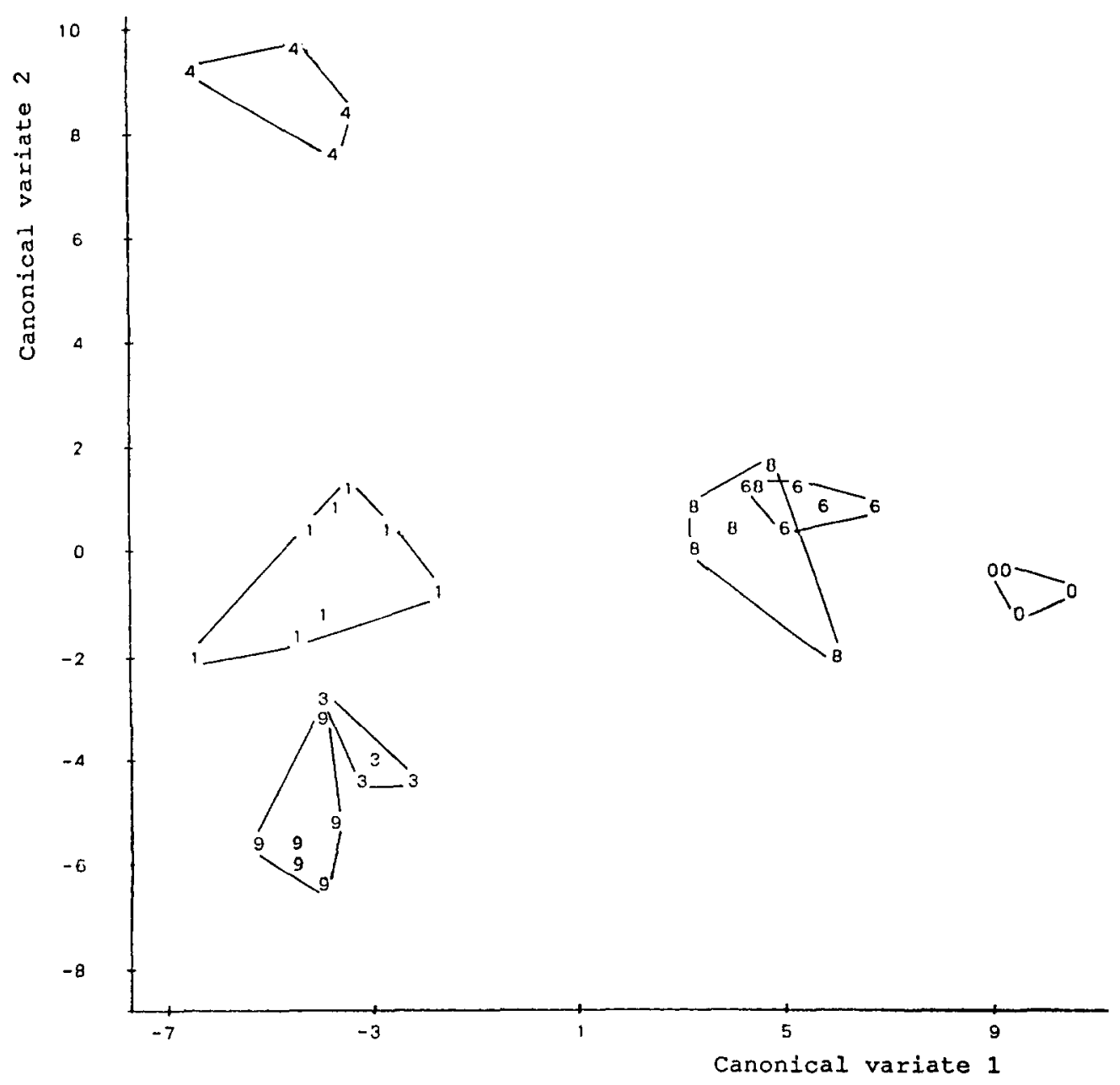

Fig. 3. Ordination of plot samples of 7 ecosystems along the first and second canonical variates showing differences among local ecosystems favored (Ecosystems 1, 6, 8, and 10) and avoided (Ecosystems 3, 4, and 9) by Kirtland's warblers in the Mack Lake burn. Number 0 stands for Ecosystem 10.

In contrast, warblers were not observed to occupy Ecosystems 3, 4, and 9. These systems were generally characterized by: (1) low topography of outwash channels having a relatively cold microclimate and the possibility of freezing temperatures in the growing season; (2) soil with heavy textured layers (loam to clay); (3) ground vegetation dominated by rice grass, wild strawberry (Fragaria virginiana Miller), and false melic (Schizachne purpurascens (Torrey) Swallen), and (4) relatively short and sparse jack pine.

Ecosystem 3 typically has soil layers of heavy texture (loam to clay). The $\mathrm{pH}$ is the highest (6.1) of all ecosystems. Ground vegetation is dominated by rice-grass, false melic, willow (Salix humilis
Marsh.), and vining honeysuckle (Lonicera dioica L.). Jack pines are sparse and short.

Ecosystem 4 occurs on the floor of outwash channels of the low-elevation area where frequent freezing temperatures are likely during the growing season. Its soil commonly has a layer of gravel and cobbles in the top $100 \mathrm{~cm}$. Sand cherry and butterweed have the highest coverage. Dominant species also include wild strawberry, serviceberry, and sedge (Carex pennsylvanica Lam.).

Ecosystem 9 of the high-elevation area is distinguished by the presence of a layer of heavy textured soil (loam to clay) in the upper $150 \mathrm{~cm}$. However, the average thickness of this layer $(42 \mathrm{~cm})$ is greater than that of Ecosystem $3(17 \mathrm{~cm})$. The dominant 


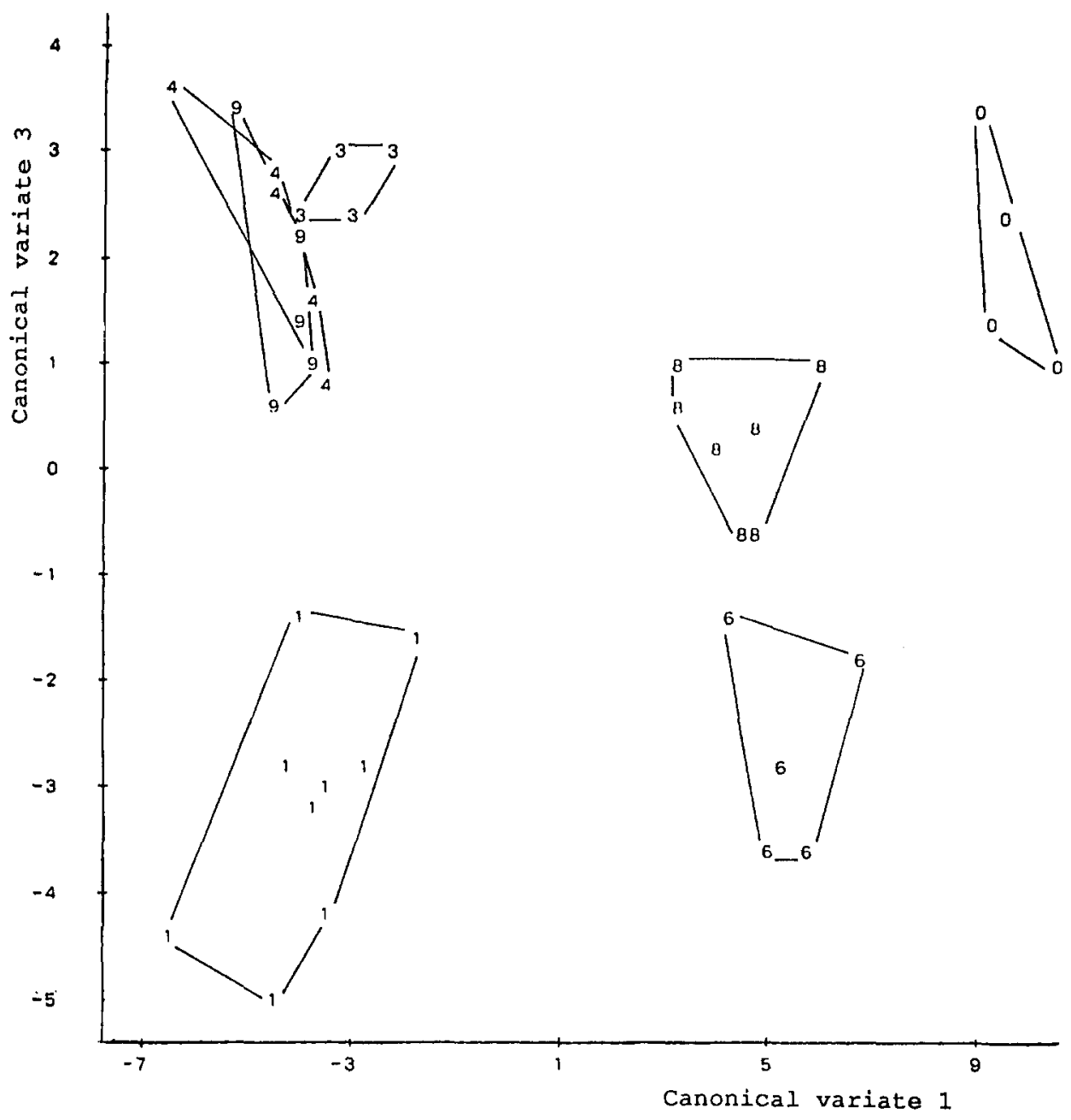

Fig. 4. Ordination of plot samples of 7 ecosystems along the first and the third canonical variates, showing differences among local ecosystems favored (Ecosystems 1, 6, 8, and 10) and avoided (Ecosystems 3, 4, and 9) by Kirtland's warblers in the Mack Lake burn. Number 0 stands for Ecosystem 10.

Table 4. Means and standard deviation (in parentheses) of variables associated with local ecosystems and occurrence of the warbler at the Mack Lake burn determined by ANOVA and Duncan's multiple range test ${ }^{1}$.

\begin{tabular}{|c|c|c|c|c|c|c|c|c|c|}
\hline \multirow[t]{2}{*}{ Variable } & \multicolumn{4}{|c|}{ Warbler present ${ }^{2}$} & \multirow[b]{2}{*}{ Ecosystem } & \multicolumn{3}{|c|}{ Warbler absent } & \multirow{2}{*}{$\begin{array}{l}\text { Significance } \\
\text { level }\end{array}$} \\
\hline & 1 & 6 & 8 & 10 & & 4 & 3 & 9 & \\
\hline Elevation(m) & $\begin{array}{l}368.0^{\mathrm{b}} \\
(2.2)\end{array}$ & $\begin{array}{l}376.6^{\mathrm{d}} \\
(3.7)\end{array}$ & $\begin{array}{l}375.2^{\mathrm{d}} \\
(4.1)\end{array}$ & $\begin{array}{l}384.2^{\mathrm{c}} \\
(4.8)\end{array}$ & & $\begin{array}{l}358.2^{\mathrm{a}} \\
(3.6)\end{array}$ & $\begin{array}{l}369.2^{b} \\
(2.1)\end{array}$ & $\begin{array}{l}375.6^{\mathrm{d}} \\
(3.4)\end{array}$ & 0.0001 \\
\hline $\begin{array}{l}\text { Depth of depressions } \\
\text { or channels }(\mathrm{m})\end{array}$ & $0.0^{\mathrm{b}}$ & $0.0^{\mathrm{b}}$ & $0.0^{\mathrm{b}}$ & $0.0^{\mathrm{b}}$ & & $\begin{array}{l}7.6^{\mathrm{a}} \\
(3.6)\end{array}$ & $0.0^{\mathrm{b}}$ & $0.0^{b}$ & 0.0001 \\
\hline $\begin{array}{l}\text { Depth to loam or clay } \\
\text { band }(0-4 \mathrm{~m})\end{array}$ & $>4.0^{c}$ & $>4.0^{c}$ & $>4.0^{c}$ & $>4.0^{\mathrm{c}}$ & & $>4.0^{\mathrm{b}}$ & $\begin{array}{l}1.4^{\mathrm{a}} \\
(0.7)\end{array}$ & $\begin{array}{l}0.9^{\mathrm{a}} \\
(0.2)\end{array}$ & 0.0001 \\
\hline $\begin{array}{l}\text { Total thickness of loam } \\
\text { and clay }(0-1.5 \mathrm{~m})\end{array}$ & $0.0^{c}$ & $0.0^{\mathrm{c}}$ & $0.0^{\mathrm{c}}$ & $0.0^{c}$ & & $0.0^{c}$ & $\begin{array}{l}0.2^{\mathrm{b}} \\
(0.2)\end{array}$ & $\begin{array}{l}0.4^{\mathrm{a}} \\
(0.2)\end{array}$ & 0.0001 \\
\hline $\begin{array}{l}\text { Percent of pebbels and } \\
\text { cobbles }(0-150 \mathrm{~cm})\end{array}$ & $\begin{array}{l}3.4^{\mathrm{b}} \\
(7.5)\end{array}$ & $\begin{array}{l}2.7^{\mathrm{b}} \\
(3.2)\end{array}$ & $\begin{array}{l}4.1^{b} \\
(4.7)\end{array}$ & $\begin{array}{l}0.9^{b} \\
(0.8)\end{array}$ & & $\begin{array}{l}15.1^{\mathrm{a}} \\
(9.3)\end{array}$ & $\begin{array}{l}1.4^{b} \\
(1.4)\end{array}$ & $\begin{array}{l}3.3^{b} \\
(2.9)\end{array}$ & 0.007 \\
\hline
\end{tabular}


Table 4. Continued.

\begin{tabular}{|c|c|c|c|c|c|c|c|c|c|}
\hline \multirow[t]{2}{*}{ Variable } & \multicolumn{4}{|c|}{ Warbler present ${ }^{2}$} & \multirow[b]{2}{*}{ Ecosystem } & \multicolumn{3}{|c|}{ Warbler absent } & \multirow{2}{*}{$\begin{array}{l}\text { Significance } \\
\text { level }\end{array}$} \\
\hline & 1 & 6 & 8 & 10 & & 4 & 3 & 9 & \\
\hline Average $\mathrm{pH}(30-150 \mathrm{~cm})$ & $\begin{array}{l}5.0^{\mathrm{c}} \\
(0.3)\end{array}$ & $\begin{array}{l}5.5^{\mathrm{abc}} \\
(0.3)\end{array}$ & $\begin{array}{l}5.8^{\mathrm{ab}} \\
(0.3)\end{array}$ & $\begin{array}{l}5.2^{\mathrm{bc}} \\
(0.4)\end{array}$ & & $\begin{array}{l}5.9^{\mathrm{a}} \\
(0.5)\end{array}$ & $\begin{array}{l}6.1^{\mathrm{a}} \\
(1.1)\end{array}$ & $\begin{array}{l}5.7^{\mathrm{abc}} \\
(0.6)\end{array}$ & 0.009 \\
\hline $\begin{array}{l}\text { Depth to textural bands } \\
\qquad(0-4 \mathrm{~m})\end{array}$ & $>4.0^{\mathrm{b}}$ & $>4.0^{\mathrm{b}}$ & $\begin{array}{l}2.2^{\mathrm{a}} \\
(3.4)\end{array}$ & $>4.0^{\mathrm{b}}$ & & $>4.0^{\mathrm{b}}$ & $>4.0^{\mathrm{b}}$ & $>4.0^{\mathrm{b}}$ & 0.009 \\
\hline $\begin{array}{l}\text { Openness class in } \\
\text { general area }(1-3)^{4}\end{array}$ & $\begin{array}{l}2.1^{\mathrm{ab}} \\
(0.7)\end{array}$ & $\begin{array}{l}1.6^{\mathrm{ab}} \\
(0.6)\end{array}$ & $\begin{array}{l}2.4^{\mathrm{b}} \\
(0.8)\end{array}$ & $\begin{array}{l}2.0^{\mathrm{ab}} \\
(0.8)\end{array}$ & & $\begin{array}{l}1.2^{\mathrm{a}} \\
(0.5)\end{array}$ & $\begin{array}{l}1.3^{\mathrm{a}} \\
(0.5)\end{array}$ & $\begin{array}{l}1.8^{\mathrm{ab}} \\
(0.4)\end{array}$ & 0.03 \\
\hline $\begin{array}{l}\text { Average height of } 1 \mathrm{st} \\
\text { living } \mathrm{JP}^{5} \text { branch }(\mathrm{cm})\end{array}$ & $\begin{array}{l}14.7^{c} \\
(5.4)\end{array}$ & $\begin{array}{l}21.2^{\mathrm{abc}} \\
(8.6)\end{array}$ & $\begin{array}{l}23.0^{\mathrm{a}} \\
(5.0)\end{array}$ & $\begin{array}{l}22.3^{\mathrm{ab}} \\
(7.9)\end{array}$ & & $\begin{array}{l}22.8^{\mathrm{a}} \\
(7.1)\end{array}$ & $\begin{array}{l}14.3^{\mathrm{c}} \\
(2.9)\end{array}$ & $\begin{array}{l}22.2^{\mathrm{ab}} \\
(6.7)\end{array}$ & 0.03 \\
\hline $\begin{array}{c}\text { Basal diameter of } \\
\text { oak snags }(\mathrm{cm})\end{array}$ & $\begin{array}{l}0.9^{\mathrm{a}} \\
(3.0)\end{array}$ & $0.0^{\mathrm{a}}$ & $\begin{array}{l}2.8^{\mathrm{a}} \\
(4.8)\end{array}$ & $\begin{array}{l}9.7^{b} \\
(6.6)\end{array}$ & & $0.0^{\mathrm{a}}$ & $\begin{array}{l}1.8^{\mathrm{a}} \\
(3.7)\end{array}$ & $0.0^{\mathrm{a}}$ & 0.002 \\
\hline $\begin{array}{l}\text { Average height of } \\
\text { dominant oaks (m) }\end{array}$ & $\begin{array}{l}0.2^{\mathrm{a}} \\
(0.2)\end{array}$ & $\begin{array}{l}0.8^{\mathrm{ab}} \\
(0.5)\end{array}$ & $\begin{array}{l}1.9^{b} \\
(1.5)\end{array}$ & $\begin{array}{l}1.4^{\mathrm{ab}} \\
(1.7)\end{array}$ & & $\begin{array}{l}0.2^{\mathrm{a}} \\
(0.3)\end{array}$ & $\begin{array}{l}1.3^{\mathrm{ab}} \\
(1.5)\end{array}$ & $\begin{array}{l}1.3^{\mathrm{ab}} \\
(0.8)\end{array}$ & 0.03 \\
\hline Number of oak clumps 6 & $\begin{array}{l}0.9^{c} \\
(1.5)\end{array}$ & $\begin{array}{l}8.6^{\mathrm{ab}} \\
(6.4)\end{array}$ & $\begin{array}{l}7.1^{\mathrm{abc}} \\
(3.4)\end{array}$ & $\begin{array}{l}11.5^{\mathrm{a}} \\
(12.3)\end{array}$ & & $\begin{array}{l}1.2^{b c} \\
(1.6)\end{array}$ & $\begin{array}{l}5.0^{\mathrm{abc}} \\
(8.0)\end{array}$ & $\begin{array}{l}3.8^{\mathrm{bc}} \\
(2.5)\end{array}$ & 0.02 \\
\hline Number of oak seedlings & $\begin{array}{l}0.6^{a} \\
(0.8)\end{array}$ & $\begin{array}{l}6.2^{\mathrm{ab}} \\
(4.0)\end{array}$ & $\begin{array}{l}6.6^{a b} \\
(3.3)\end{array}$ & $\begin{array}{l}15.5^{c} \\
(14.0)\end{array}$ & & $\begin{array}{l}1.2^{\mathrm{a}} \\
(1.8)\end{array}$ & $\begin{array}{l}2.8^{\mathrm{a}} \\
(1.9)\end{array}$ & $\begin{array}{l}11.0^{\mathrm{bc}} \\
(6.5)\end{array}$ & 0.001 \\
\hline Number of shrub species & $\begin{array}{l}5.2^{b} \\
(1.7)\end{array}$ & $\begin{array}{l}11.2^{\mathrm{a}} \\
(2.8)\end{array}$ & $\begin{array}{l}8.7^{\mathrm{a}} \\
(3.4)\end{array}$ & $\begin{array}{l}9.0^{\mathrm{a}} \\
(4.1)\end{array}$ & & $\begin{array}{l}7.8^{b} \\
(1.9)\end{array}$ & $\begin{array}{l}9.3^{\mathrm{a}} \\
(0.5)\end{array}$ & $\begin{array}{l}10.5^{\mathrm{a}} \\
(2.1)\end{array}$ & 0.002 \\
\hline Number of lichen species & $\begin{array}{l}1.6^{\mathrm{b}} \\
(1.0)\end{array}$ & $\begin{array}{l}1.6^{b} \\
(0.9)\end{array}$ & $\begin{array}{l}3.0^{\mathrm{a}} \\
(1.0)\end{array}$ & $\begin{array}{l}1.7^{b} \\
(1.0)\end{array}$ & & $\begin{array}{l}2.0^{\mathrm{a}} \\
(1.0)\end{array}$ & $\begin{array}{l}2.0^{\mathrm{a}} \\
(0.8)\end{array}$ & $\begin{array}{l}1.2^{\mathrm{b}} \\
(0.4)\end{array}$ & 0.03 \\
\hline Quercus ellipsoidalis ${ }^{7}$ & $\begin{array}{l}1.3^{a b} \\
(1.9)\end{array}$ & $\begin{array}{l}4.0^{a b} \\
(4.6)\end{array}$ & $\begin{array}{l}6.2^{b} \\
(4.3)\end{array}$ & $\begin{array}{l}16.5^{\mathrm{c}} \\
(9.0)\end{array}$ & & $\begin{array}{l}0.4^{\mathrm{a}} \\
(0.6)\end{array}$ & $\begin{array}{l}3.0^{\mathrm{ab}} \\
(4.1)\end{array}$ & $\begin{array}{l}3.5^{\mathrm{ab}} \\
(2.1)\end{array}$ & 0.0001 \\
\hline Amelanchier sanguinea & $\begin{array}{l}<0.1^{b} \\
(0.1)\end{array}$ & $\begin{array}{l}0.1^{\mathrm{b}} \\
(0.1)\end{array}$ & $\begin{array}{l}<0.1^{b} \\
(0.1)\end{array}$ & $0.0^{\mathrm{b}}$ & & $\begin{array}{l}1.4^{\mathrm{a}} \\
(0.6)\end{array}$ & $\begin{array}{l}1.9^{\mathrm{a}} \\
(2.8)\end{array}$ & $\begin{array}{l}0.1^{b} \\
(0.1)\end{array}$ & 0.009 \\
\hline Gaylussacia baccata & $0.0^{\mathrm{a}}$ & $0.0^{\mathrm{a}}$ & $0.0^{\mathrm{a}}$ & $\begin{array}{l}3.8^{b} \\
(5.7)\end{array}$ & & $0.0^{\mathrm{a}}$ & $0.0^{\mathrm{a}}$ & $0.0^{\mathrm{a}}$ & 0.02 \\
\hline Prunus pumila & $\begin{array}{l}3.3^{\mathrm{a}} \\
(4.6)\end{array}$ & $\begin{array}{l}1.3^{\mathrm{a}} \\
(1.2)\end{array}$ & $\begin{array}{l}0.3^{\mathrm{a}} \\
(0.3)\end{array}$ & $\begin{array}{l}0.4^{a} \\
(0.7)\end{array}$ & & $\begin{array}{l}13.5^{b} \\
(10.3)\end{array}$ & $\begin{array}{l}0.7^{\mathrm{a}} \\
(0.6)\end{array}$ & $\begin{array}{l}0.4^{a} \\
(0.6)\end{array}$ & 0.0001 \\
\hline Rosa blanda & $\begin{array}{l}<0.1^{\mathrm{a}} \\
(0.1)\end{array}$ & $\begin{array}{l}<0.1^{\mathrm{a}} \\
(0.1)\end{array}$ & $\begin{array}{l}<0.1^{\mathrm{a}} \\
(0.1)\end{array}$ & $\begin{array}{l}<0.1^{a} \\
(0.1)\end{array}$ & & $\begin{array}{l}0.1^{\mathrm{a}} \\
(0.1)\end{array}$ & $\begin{array}{l}0.1^{a} \\
(0.1)\end{array}$ & $\begin{array}{l}0.3^{b} \\
(0.3)\end{array}$ & 0.01 \\
\hline Aster ptarmicoides & $0.0^{\mathrm{a}}$ & $\begin{array}{l}0.02^{b} \\
(0.03)\end{array}$ & $0.0^{\mathrm{a}}$ & $0.0^{\mathrm{a}}$ & & $0.0^{\mathrm{a}}$ & $0.0^{\mathrm{a}}$ & $0.0^{\mathrm{a}}$ & 0.02 \\
\hline Maianthemum canadense & $0.0^{\mathrm{a}}$ & $\begin{array}{l}0.1^{\mathrm{a}} \\
(0.1)\end{array}$ & $\begin{array}{l}<0.1^{a} \\
(0.1)\end{array}$ & $0.0^{\mathrm{a}}$ & & $\begin{array}{l}<0.1^{\mathrm{a}} \\
(0.1)\end{array}$ & $\begin{array}{l}0.2^{\mathrm{a}} \\
(0.2)\end{array}$ & $\begin{array}{l}0.4^{b} \\
(0.3)\end{array}$ & 0.003 \\
\hline Senecio pauperculus & $0.0^{\mathrm{a}}$ & $\begin{array}{l}0.02^{\mathrm{a}} \\
(0.03)\end{array}$ & $0.0^{\mathrm{a}}$ & $0.0^{\mathrm{a}}$ & & $\begin{array}{l}0.1^{\mathrm{b}} \\
(0.2)\end{array}$ & $0.0^{\mathrm{a}}$ & $0.0^{\mathrm{a}}$ & 0.02 \\
\hline
\end{tabular}

${ }^{1}$ Data are from Zou (1988); ${ }^{2}$ Presence based on sightings of singing males in the ecosystems; ${ }^{3}$ Ecosystems with the same letters are not significantly different $(\mathrm{P}=0.05) ;{ }^{4}$ Dense $=3$; medium dense $=2$; and sparse $=1 .{ }^{5} \mathrm{JP}=$ jack pine; ${ }^{6}$ Numbers per $10 \times 20$-m plot; ${ }^{7}$ Values are percent coverage, same for the following species.

species include rice-grass, bracken fern, willow, and false melic. Other species include trembling aspen (Populus tremuloides Michx.), black cherry (Prunus serotina Ehrh.), and red maple.

\section{Conclusions}

A landscape ecosystem approach was used to identify local ecosystem types in recently burned jack pine-oak forest surrounding Mack Lake. During their initial period of occupancy of the area, Kirtland's warblers were observed not to occur at random, but in a pattern coincident with the broad landscape patterns of physiography, soil, and vegetation. Some local ecosystem types appeared favorable to warbler occurrence, whereas other types were not observed to be occupied. Specific conditions of the topography, soil, and woody and her- 
baceous vegetation were found associated with the observed warbler occurrence in its summer habitat. Warblers were found in those areas with warm microclimates, abundant jack pine, with low shrubs, on light, sandy soils. This research provides additional information about warbler habitat conditions and a guide as to where to concentrate the yearly census of the warbler population. It also provides a baseline to monitor the expected change in warbler occupancy of the burned area as the initial areas of occupancy become unfavorable and other areas become more favorable.

\section{Acknowledgements}

We wish to thank in particular Mike Bosio for his field leadership during the 1986 field season and his assistants, Phil Stuart, Jim Prine, and Tom Simpson. We also thank Kirk Radford and William Levenick for field assistance in 1987 and 1988, respectively. We especially thank Cameron Kepler, John Probst, Paul Sykes, and Carol Bocetti for their invaluable assistance in locating the territories of the warblers. We appreciate the generous contribution of time, support, and information by Dr. Sylvia Taylor and Jerry Weinrich. The support and encouragement of the Kirtland's Warbler Recovery Team, John Byelich, Chair, is greatly appreciated. Thanks also go to D. Valentine, J. Weinrich, J. Probst, and D. Binkley for reviewing the first version of the manuscript and to D.K. Hersh for help in preparing the tables. Useful suggestions and manuscript revisions were provided by F.B. Golley, C. Kepler, and an anonymous reviewer. This study was made possible by grants to the University of Michigan in 1986, 1987, and 1988 by the Wildlife Division of the Michigan Department of Natural Resources.

\section{References}

Archambault, L., Barnes, B.V. and Witter, J.A. 1990. Landscape ecosystems of disturbed oak forests of southeastern Michigan, USA. Can. J. For. Res. 20: 1570-1582.

Barnes, B.V. 1984. Forest ecosystem classification and mapping in Baden-Württemberg, West Germany. In Forest Land Clas- sification: Experience, Problems, Perspectives. pp. 49-65. Edited by J.G. Bockheim. Proc Symposium, NCR-102 North Central Forest Soils Committee, Society of American Foresters, USDA Forest Service, and USDA Soil Conservation Service, Madison, WI, March 1984.

Barnes, B.V. and Bosio, M. 1986. Report: Analysis of the ecosystem structure and vegetation of the Mack Lake burn: a framework for understanding the occurrence and behavior of Kirtland's warbler. Report to Wildlife Division, Michigan DNR, December 1986. 10 p.

Barnes, B.V., Pregitzer, K.S., Spies, T.A. and Spooner, V.H. 1982. Ecological forest site classification. J. For. 80: 493498.

Barnes, B.V., Theiss, C. and Zou, X. 1989. Final report: Ecosystem structure and vegetation of the Mack Lake burn: a framework for understanding the occurrence and behavior of Kirtland's warbler. Report to Michigan DNR, February 1, 1989. 48 p.

Buech, R.R. 1980. Vegetation of a Kirtland's warbler breeding area and 10 nest sites. Jack-Pine Warbler 58: 59-72.

Byelich, J., Leader. 1976. Kirtland's Warbler Recovery Plan. Michigan Dept. Nat. Res. 98 p.

Gee, G.W. and Bauder, J.W. 1986. Particle-size analysis. In Methods of Soil Analysis. Part 1: Physical and Mineralogical Methods. Second edition. pp. 383-411. Edited by A. Klute. ASA and SSSA, Madison, WI, USA.

Jenrich, R.I. 1977. Stepwise discriminant analysis. In Statistical Methods for Digital Computers, Vol. III. pp. 76-95. Edited by K. Enslein, A. Ralston and H.W. Wilf. John Wiley \& Sons, NY.

Kelley, S.T. and DeCapita, M.E. 1982. Cowbird control and its effect on Kirtland's warbler reproductive success. Wilson Bull. 94: 363-365.

McLean, E.O. 1982. Soil pH and lime requirement. In Methods of Soil Analysis. Agronomy No. 9 (part 2). pp. 199-224. Edited by A.L. Page, R.H. Miller and K.R. Keeney. ASA \& SSSA, Madison, WI.

Mardia, K.V., Kent, J.T. and Babby, J.M. 1979. Multivariate analysis. Academic Press, London.

Mayfield, H.F. 1953. A census of the Kirtland's warbler. Auk 70: $17-20$.

Mayfield, H.F. 1960. The Kirtland's warbler. Cranbrook Inst. Science, Bull. No. 40, Bloomfield Hills, MI. 242 pp.

Mayfield, H.F. 1962. 1961 decennial census of the Kirtland's warbler. Auk 79: 173-182.

Mayfield, H.F. 1972. Third decennial census of Kirtland's warbler. Auk 89: 262-268.

Michigan Weather Service. 1974. Climate of Michigan. Mich. Dept. Agri., Michigan Weather Service, Lansing, MI, USA.

Neter, J. and Wasserman, W. 1985. Applied linear statistical models. Richard D. Irwin Inc., Homewood, IL, USA.

Pregitzer, K.S. and Barnes, B.V. 1984. Classification and comparison of upland hardwood and conifer ecosystems of the Cyrus H. McCormick Experimental Forest, Upper Michigan. Can. J. For. Res. 14: 362-375.

Probst, J.R. 1985. Summer records and management implica- 
tions of Kirtland's warbler in Michigan's upper peninsula. Jack-Pine Warbler 63: 9-16.

Probst, J.R. 1986. A review of factors limiting the Kirtland's warbler on its breeding grounds. Amer. Midl. Nat. 116: 87100.

Probst, J.R. 1987. Kirtland's warbler breeding biology and habitat management. In Integrating Forest Management for Wildlife and Fish. pp. 28-35. Compiled by W. Hoekstra and J. Capp. USDA Forest Service, North Central For. Exp. Sta., Paper NC-122.

Ryel, L.A. 1978. Kirtland's warbler status, June 1978. Michigan Dept. Nat. Res., Surveys and Stat. Serv. Rept. No. 167. Lansing, MI, USA.

Ryel, L.A. 1980. Kirtland's warbler status, June 1979. JackPine Warbler 58: 30-32.

Ryel, L.A. 1981. Population change in the Kirtland's warbler. Jack-Pine Warbler 59: 76-91.

Simard, A.J., Haines, D.A., Blank, R.W. and Frost, J.S. 1983. The Mack Lake fire. USDA For. Serv. Gen. Tech. Rep. NC-83. North Central For. Exp. Sta., St. Paul, MN, USA.

Spies, T.A. and Barnes, B.V. 1985. A multi-factor ecological classification of the northern hardwood and conifer ecosystems of Sylvania recreation area, Upper Penninsula, Michigan. Can. J. For. Res. 15: 949-960.

Steel, R.G.D. and Torri, J.H. 1980. Principles and procedures of statistics. McGraw-Hill, NY, USA.

Thien, S.J 1979. A flow diagram for teaching texture-by-feeling analysis. J. Agron. Education 8: 54-55.

Trautman, M.B. 1979. Experiences and thoughts relative to Kirtland's warbler. Jack-Pine Warbler 57: 135-140.

Walkinshaw, L.H. 1983. Kirtland's warbler: The natural history of an endangered species. Cranbrook Inst. Sci. Bull No. 58, Bloomfield Hills, MI, USA. 207 pp.

Williams, B.K. 1981. Discriminant analysis in wildlife research: Theory and applications. In The Use of Multivariate Statistics in Studies of Wildlife Habitat. pp. 59-71. Edited by D.A. Capen. USDA For. Serv. Gen. Tech. Rept. RM-87.

Zou, X. 1988. Pattern of jack pine occurrence in ecosystems of Kirtland's warbler summer habitat at Mack Lake, northern Lower Michigan. M.S. thesis, Sch. Nat. Res., Univ. Michigan, Ann Arbor, MI. 91 pp. 